\title{
Moral development as the influencer of fraud detection
}

Heliantono Heliantono ${ }^{1 *}$, Itjang D. Gunawan ${ }^{2}$, Khomsiyah Khomsiyah $^{3}$, Regina J. Arsjah ${ }^{4}$

Trisakti University, Jakarta, Indonesia ${ }^{1,2,3,4}$

heliantono@gmail.com

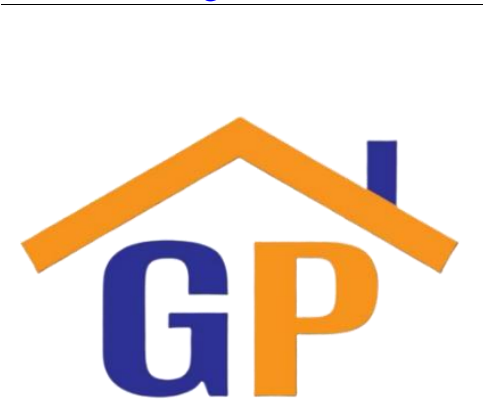

\begin{abstract}
Purpose: The purpose of the study is to analyze the influence of the external auditor's moral development, continuing professional education (CPE) on fraud, and education on fraud detection.
\end{abstract}

Research methodology: The research sample was taken randomly, and the total respondents were 171 external auditors working in public accounting firms in Indonesia. The analytical data method uses multiple linear regression. The instrument measures moral development using three scenarios, which are the auditor opinion, allowance for receivables, and cost reimbursement, with modifications made to conform with Law 5/2011 concerning public accountant.

Article History

Received on 28 January 2020

Revised on 8 April 2020

Accepted on 30 June 2020
Results: Results found that moral development and education had a significant effect on fraud detection, while CPE on fraud has no effect on fraud detection.

Limitations: One newly developed of the three scenarios measuring moral development may not be suitable for region other than Indonesia.

Contribution: The accounting red flag dimension is the dimension that has the most attention, while the dimension according to SA 240 , the perpetrator dimension, is the dimension that has the least attention.

Keywords: Kohlberg moral development, Education, CPE on fraud, Fraud detection

How to cite: Heliantono H., Gunawan, I. D., Khomsiyah, K., Arsjah, R. J. (2020). Moral development as the influencer of fraud detection. International Journal of Financial, Accounting, and Management, 2(1), 1-11.

\section{Introduction}

The issue of fraud occurs in almost every organization in all countries in the world (Firth, Mo, \& Wong, 2005; Greer \& Tonge, 2006; and ACFE, 2018b) with an estimated value of loss of 5\% of the sales value. If the loss is multiplied by the gross world product, the estimated value of losses is USD3.5 trillion, USD3.7 trillion, USD3.7 trillion, and USD4 trillion in 2012, 2014, 2016 and 2018, respectively,(ACFE, 2012; ACFE, 2014; ACFE, 2016a; and ACFE, 2018a). The Association of Certified Fraud Examiners (ACFE) detected and examined 1,388; 1,483; 2,410; and 2,690 cases of fraud in 2012, 2014, 2016, and 2018 respectively with increasing losses USD6.3 billion in 2016 and USD 7 billion in 2018, (ACFE, 2016b; ACFE, 2018a). Financial statement fraud does not always be detected and revealed since various motivations underlying it and the many methods for conducting financial statement fraud. However, in reality, the detection of fraud is not as easy as it says, such as the results of research find even external auditors who have professional skepticism may not be able to detect fraud (Jamal, Johnson, \& Berryman, 1995).

Previous research related to factors that influence fraud detection relating to individual aspects, among others, is the factor of moral development. The research includes examining whether auditors who have high levels of moral development will be more sensitive to red flags of fraud. External auditors who 
have high moral development show a better ability to detect fraud (Bernardi, 1994). Similar results found that external auditors who have higher moral development are considered more able to identify ethical issues, which are issues of audit dilemmas (Sweeney \& Roberts, 1997). External auditors with higher moral competence are better able to withstand third party pressure and are not easily influenced by the norms and rules of the group (Sweeney \& Roberts, 1997). Gender, age, and education affect the ability to detect fraud (Dickerson, 2009) and (Gadjali \& Birton, 2014). The purpose of this study is to determine the effect of moral development, education, and CPE fraud on fraud detection.

\section{Literature review and hypotheses development}

The condition of fraud that is often used to analyze the behavior of fraud is the fraud triangle model. Cressey (ACFE, 2017) researched those who violated the trust or trust entrusted to them. A trusted person can be a violator of trust when he considers himself to have financial problems that cannot be shared with others. That person is aware that this problem can be solved secretly by violating the position of trust, and his daily behavior allows him to adjust the view of himself as someone who can be trusted in using the funds or wealth entrusted to him (ACFE, 2017 and Dorminey, Fleming, Kranacher, \& Riley, 2012). Fraud Triangle is a model to explain the factors that cause a person or management to commit fraud in their work. The Fraud Triangle consists of three components, which together lead to behavior to commit fraud, which is Pressure, Opportunity and Rationalization (ACFE, 2017). The pressure is a pressing situation (the need for funds) and the perceived burden that cannot be shared with others (perceived non-shared financial need). Opportunity is a condition that gives a person or company an opportunity that allows for fraud. Rationalization is a demographic of a person or environment and a set of values that justifies certain parties to commit fraud.

Ajzen (1991) argues that the theory of planned behavior provides a conceptual framework that is useful to explain the complex of human social behavior. This theory combines several central concepts in social and behavioral sciences and seals these concepts so that it is possible to predict and understand certain behaviors in certain contexts. Attitudes toward behavior, subjective norms regarding behavior, and perceptions of behavioral control are used to predict intention for the behavior with a high degree of accuracy. Furthermore, this intention, combined with perceptions of behavioral control, can explain most behavioral variations. The theory of planned behavior pays attention to attitudes, subjective norms, and perceived behavioral control to beliefs that underlie these behaviors. Although there is ample evidence for a significant relationship between beliefs and attitudes toward behavior, between normative beliefs and subjective norms, and between control beliefs and perceived control behaviors, the exact form of this relationship is still uncertain. Attitudes toward behavior, subjective norms, perceptions of behavior control, and intentions, each expressing different aspects of behavior, and each of them can serve as a reduction in the likelihood of the behavior to be taken. The beliefs that underlie behavior can provide the detailed description needed to obtain basic information about the determinants of the behavior. At this level of confidence can be learned about a person's unique factors that encourage people to behave in accordance with things that interest him and encourage others to follow certain actions.

\section{Fraud detection}

Fraud is defined as the deliberate act of using a position to enrich oneself through the improper use of an organization's resources or wealth (ACFE, 2016b). Fraud is an intentional unlawful act for a particular purpose (manipulation or giving false reports to other parties), carried out by people from within or outside the organization for profit, (ACFE, 2016b). Audit Standard 240 (IAPI, 2013) in the Public Accountant Professional Standards defines fraud, as an intentional act by one or more individuals in management, the party responsible for governance, employees, or third parties, which involves the use deception to gain an unfair advantage or break the law. The fraud referred to in this study is limited to the definition of classification of financial reporting fraud and misuse of assets, excluding the fraud classification of corruption. This exclusion is in accordance with the definition of fraud by the responsibility of external auditors as studied by Hayes, Wallage, and Gortemaker (2014). They mentioned that the context of fraud was defined as a deliberate financial statement mistake. There are two main categories of financial statement fraud, which are financial reporting fraud and misuse of 
assets. Fraud detection measurement is adopted from Fullerton and Durtschi (2004) study, which dimensions and indicators consist of: first, dimension Corporate Red Flags (indicators High Fraud Corporate Cultures and High Fraud Industry Environment), second, dimension Perpetrator Red Flags (indicators Personal Financial Pressure, Perpetrator Opportunities, Perpetrator Rationalizations, Perpetrator Behavior Changes, and Demographic of Perpetrator), and third, dimension Accounting Red Flags (indicators Accounting Practice Indicators, and Financial Statement Indicators). The development of measurement tools for detecting fraud from Fullerton \& Durtschi (2004) uses three dimensions, which are environmental factors, individual factors, and accounting factors. In the second dimension, the demographic indicators of individual actors have been modified by not using them in this study; because it contains problems between groups, races, and religions and is not in accordance with Pancasila as a state base.

Welton and Guffey (2009) developed an instrument to measure the level of moral development in the domain of accounting and business decision making. The instrument consists of four scenarios consisting of twelve statements and four sequences for each scenario. These scenarios are the opinion, bankruptcy, bank audit, and reimbursement. This study using Welton and Guffey's instruments measuring the moral development of external auditors with scenario modification of the implementation of Law Number 5 of 2011 concerning Public Accountants. The new auditing scenario is developed while maintaining the element of independence value and staying in accordance with the laws and regulations for assurance services in Indonesia, and on the other hand, maintaining the ethical dilemma embedded in the scenario. The second scenario, which is the bankruptcy scenario, is no longer used since it relates to business owners or business management situations and is not relevant to the daily issues of external auditors. The third and fourth scenarios, the bank audit scenario and reimbursement scenario, are relevant and apropriate in the domain of external auditors. Therefore, these three scenarios are used as a measurement tool for the level of moral development of external auditors as the Ethical Issue Test for External Auditors. Conceptual frameworks function as making research models and designing influences between variables.

Figure 1. Conceptual Framework

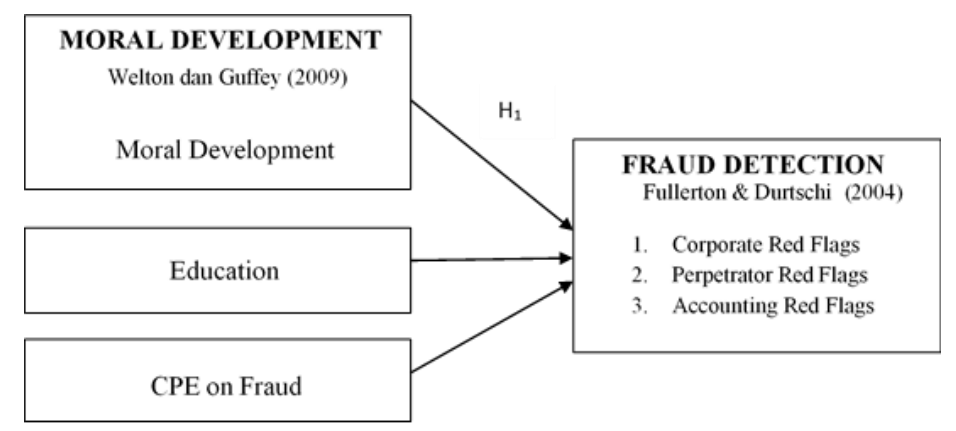

Research results that external manager auditors have high moral development show better ability to detect fraud (Pincus, 1994). Whereas research by Abdolmohammadi and Owhoso (2000) found that the moral development of senior auditors influences the detection of fraud. One's moral development is strongly influenced by experience (Jones, 1991). Referring to the findings of several previous studies above found that the development of auditors has a positive effect on the detection of fraud, this research proposed hypothesis as follows.

\section{$H_{1}$ : Moral development of external auditors have a positive effect on the detection of fraud}

\section{Research methodology}

The study uses quantitative-based by using primary data. The data used are collected using a questionnaire as a research instrument. The sampling technique is random sampling. The respondent of the study is the external auditor who works at a public accounting firm with the position as partner, audit manager, supervisor, and senior auditor. The sample calculation uses the maximum likelihood estimation method, and the minimum sample is 100 respondents (Hair, Black, Babin, \& Anderson, 2014). Data analysis using multiple linear regression and statistical tool uses SPSS software under 
windows. The dependent variable is fraud detection, and the independent variables is moral development, the control variables are education and CPE fraud

Formerly Fullerton and Durtschi (2004) use 42 instruments to measure the fraud detection variable. In this study, instruments used is 38 since the demography dimension consisting of 4 instruments contains inter-group, racial, and religion issue which do not suit the Pancasila as the foundation principle of Indonesia. While the Moral development measurement refers to Welton and Guffey (2009) consisting of three scenarios, 36 issues, and 12 sequencing. One of the three scenarios of moral development was modified because it was in accordance with Law No. 5/2011 regarding public accounts as a novelty from this study, the Audit Opinion scenario.

The analytical data uses multiple linear regression with the equation

$$
\mathrm{FD}=\beta 0+\beta 1 \mathrm{MD}+\beta 2 \mathrm{EDU}+\beta 3 \mathrm{CPE}+\mathrm{e},
$$

where

$$
\begin{aligned}
& \mathrm{Y}=\text { fraud detection, } \\
& \beta 0=\text { regression constant, } \\
& \mathrm{MD}=\text { moral development } \\
& \mathrm{EDU}=\text { education } \\
& \mathrm{CPE}=\mathrm{CPE} \text { on fraud }
\end{aligned}
$$

Before analyzing using multiple linear regression, the questionnaire instrument was tested to its validity and reliability and the classic assumption test on variables. Analysis of determination (R Square) is calculated to see how much the independent variable is able to explain or could form a dependent variable. Hypothesis testing partially (t-test) and simultaneous (F test) with an error tolerance level of 5 percent. Results of the analysis show moral development, education, CPE fraud, have a positive and significant effect on fraud detection.

\section{Results and discussions}

The results of data processing for the validity and reliability instrument testing are 38 indicators that are all valid, and reliable. In moral development, variable four sequences are also valid and show good reality. The results of the normality test concluded that the data were normally distributed. The multicollinearity test results that there are no multicollinearity problems. The heteroscedasticity test, shows that there is no heteroscedasticity, so the regression model is used to predict fraud detection.

Respondent characteristics were analyzed based on demographic data, including gender, marital status, age, education, position, and work experience as an external auditor. The characteristics of respondents are presented in Table 1 below.

\section{Descriptive Statistics}

Table 1: Respondents Characteristics

\begin{tabular}{llrr}
\hline \multicolumn{1}{c}{ Descriptive } & \multicolumn{1}{c}{ Category } & Frequency & Percent \\
\hline Gender & Male & 113 & $66.1 \%$ \\
& Female & 58 & $33.9 \%$ \\
Marriage Status & Married & 111 & $64.9 \%$ \\
& Not Married & 60 & $35.1 \%$ \\
Age & & & \\
& 25-30 year & 47 & $27.5 \%$ \\
& 31-39 year & 78 & $45.6 \%$ \\
& 40-49 year & 25 & $14.6 \%$ \\
& 50-59 year & 16 & $9.4 \%$ \\
& 60-69 year & 4 & $2.3 \%$ \\
& $>70$ year & 1 & $0.6 \%$
\end{tabular}




\begin{tabular}{llrr}
\hline \multicolumn{1}{c}{ Descriptive } & Category & Frequency & Percent \\
\hline Position & Partner & 46 & $26.9 \%$ \\
& Manager & 24 & $14 \%$ \\
& Supervisor & 19 & $11.1 \%$ \\
& Senior & 82 & $48 \%$ \\
& & & \\
Education & Diploma & 16 & $9.4 \%$ \\
& Undergraduate & 126 & $73.7 \%$ \\
& Master & 26 & $15.2 \%$ \\
& Doctoral & 3 & $1.8 \%$ \\
Work experience & & & \\
& 3-5 year & 38 & $22.2 \%$ \\
& 6-10 year & 48 & $28.1 \%$ \\
& $11-15$ year & 41 & $24 \%$ \\
& $>15$ year & 44 & $25.7 \%$ \\
CPE Fraud & Yes & 59 & $34.5 \%$ \\
& No & 112 & $65.5 \%$ \\
\hline Source: Data processed & & &
\end{tabular}

Table 1 shows that in the study sample, male external auditors amounted to $66.1 \%$, so the number of male respondents is higher than women. More men than women because the work as an auditor often faces report deadlines, causing auditors to have to complete their work overtime. In general, men have higher flexibility than women working beyond regular working hours. Based on marital status, more auditors were married (64.9\%) than those who were not married. This percentage is related to the age of the majority of external auditors who are mature people. Based on age classification, it was found that most auditors were in the cohort age 31-39 years (45.5\%), and if added by auditors aged between 25-30 years, the number reaches $73 \%$. This number means that most auditors are the younger generation.

Most auditor positions in the accounting firm are senior (48\%), while auditors with positions as supervisors and managers are the least (14\% and $11.1 \%)$ due to a strict and lengthy process of promotion to become supervisors and managers in public accounting firms. In addition, most auditors' working objectives at an accounting firm mainly are to gain knowledge and experience. When they feel that they have enough knowledge and experience, but waiting too long for promotion to supervisor, they tend to resign from their accounting company.

Most auditor level of education is undergraduates (73.7\%), and the least is auditors with doctoral education $(1.8 \%)$ because most accounting firm minimum educational requirements are undergraduates. Some external auditors have diploma education (9.4\%), usually due to having long working experience or/and working in a single practitioner's office. Classification based on working experience, there tends to be an even distribution of auditors with 3-5 years of work experience, 6-10 years, 11-15 years, and more than 15 years, but auditors with 6-10 years $(28.1 \%)$ are the most. This distribution is related to being a senior auditor who takes five years, while to become a supervisor/manager must enter a separate selection process. Quite several external auditors have worked for longer than 15 years, and the reason mainly is they want to work as an auditor.

Furthermore, to improve knowledge, skills, and attitudes as an auditor, an auditor must follow the continuing professional education (CPE). Within a year, an auditor must take at least 5 (five) days of $\mathrm{CPE}$ activities. Besides, auditors need to improve their competence by participating in various certifications. Table 2 below presents the auditor's activities in CPE during the past year as well as the auditor's certification, including CPE on fraud detection. So far, IAPI has put more emphasis on SAK and SPAP training since these two subjects are very dynamic to change.

Tabel 2: Descriptive Statistics Variable 


\begin{tabular}{|c|c|c|c|c|c|}
\hline Variable & $\mathrm{N}$ & Minimum & Maximum & Mean & Std. Deviation \\
\hline Fraud Detection & & & & 3.24 & .66 \\
\hline 1. Corporate Red Flags & & 1.00 & 5.00 & 3.14 & .77 \\
\hline 2. Perpetrator Red Flags & & 1.00 & 4.33 & 2.71 & .73 \\
\hline 3. Accounting Red Flags & & 1.00 & 5.00 & 3.99 & .80 \\
\hline $\begin{array}{l}\text { Moral Development } \\
\text { Moral Development }\end{array}$ & & 6.67 & 80.00 & 35.73 & 14.34 \\
\hline
\end{tabular}

Source: Data processed

Table 2 shows that for each dimension of the research fraud detection variable, there were respondents who answered on a score of 1 , which means the respondent a not interested to seek deeper information on the given situation and score of 5 when the respondent is very interested in seeking information. The average score of the fraud detection is $3.24 \mathrm{n}$; this score is higher than the standard deviation indicating the data is good.

The lowest score was found in the perpetrator dimension of 2.71 , reflects the auditor's perspective that the perpetrator dimension, which consists of pressure, opportunity, and rationalization, is not considered too important by external auditors in general. As a result, the mean of fraud detection value was lower than the other dimensions; even among the three dimensions of fraud detection (environment, perpetrator, and accounting), the perpetrator dimension was discussed deeply in the public accountant professional standard SA 240, (IAPI, 2013). The highest mean fraud detection value is the accounting dimension (3.99), which indicates that external auditors pay the most attention to the numbers presented in the financial statements as the better signal (red flags) than the signal on perpetrator and environment.

The minimum $\mathrm{P}$ score for the moral development variable is 6.67 , while the maximum $\mathrm{P}$ score reaches 80. The average $P$ score is 35.73 . The average value of the Indonesian auditor's $P$ score 35.73 is below the auditor's P score in the US at 36.60 and above auditors $\mathrm{P}$ score in the northeast of 44.18. The Indonesian auditor's P-score is higher than the auditor P score in Southeastern US which is 33.05 and higher than the auditor P score in Australia which is 34.20 or 35.19 and is still higher than the $\mathrm{P}$ score of auditors in Ireland which is 34.20, (Bailey, Scott, \& Thoma, 2010).

\section{Statistical Test Results and Discussion}

Multiple linear regression analysis

Research results as show in Table 3. The results of the multiple linear regression equation:

$$
\begin{aligned}
\mathrm{Y} & =\beta_{0}+\beta_{1} \mathrm{X}_{1}+\beta_{2} \mathrm{X}_{2}+\beta_{3} \mathrm{X}_{3}+\mathrm{e} \\
& =2.574+1.438 \mathrm{X} 1+1.186 \mathrm{X} 3+0.054 \mathrm{X} 2
\end{aligned}
$$

\begin{tabular}{|c|c|c|c|c|}
\hline Variable & $\begin{array}{l}\text { Coefficient } \\
\text { Regression } \\
\end{array}$ & $t_{\text {-test }}$ & $t_{\text {-table }}$ & Sig. \\
\hline Constanta & 2.574 & 2.668 & 1.645 & 0.008 \\
\hline Moral Development & 1.438 & 4.584 & 1.645 & 0.000 \\
\hline Education & 1.186 & 3.766 & 1.645 & 0.000 \\
\hline CPE on Fraud & 0.054 & 0.148 & 1.645 & 0.882 \\
\hline $\mathrm{R}$ & 0.426 & & & \\
\hline $\mathrm{R}^{2}$ & 0.181 & & & $\alpha=5 \%$ \\
\hline $\begin{array}{l}\text { F-test } \\
\mathrm{N}\end{array}$ & $\begin{array}{l}12.308 \\
171\end{array}$ & & 2.68 & 0.000 \\
\hline
\end{tabular}

$\mathrm{R}$ square value is a coefficient of determination of 0.181 , which shows the amount of contribution from the influence of the independent variable on the dependent variable. Thus, it can be concluded that the amount of contribution from the influence of moral development, education, CPE fraud variables together has a significant effect on fraud detection by $18.1 \%$. In contrast, the remaining $81.9 \%$ is the influence of other factors not included in this study. 
Table 3 shows that moral development has a significant level of less than $0.05(0.000<0.05)$, the Hypothesis 1 is accepted, it can be concluded that moral development has a positive and significant effect on fraud detection. To answer the second hypothesis $t$ arithmetic for education variable is 3,766 > 1,645 , so the Hypothesis 2 is accepted, it can be concluded that education has a positive and significant effect on fraud detection.

Furthermore, the $\mathrm{t}$ count number of CPE on fraud is 0.148 , since the value of $\mathrm{t}$-count less than t-Table $(0.148<1.645)$ the Hypothesis 3 is rejected, meaning that there is no effect of CPE on fraud on fraud detection.

Table 4 Correlations between Variable Dimensions

\begin{tabular}{|c|c|c|c|c|}
\hline Variable & & \multicolumn{3}{|c|}{ Fraud Detection } \\
\hline & Dimension & $\begin{array}{l}\text { Corporate } \\
\text { Red Flags }\end{array}$ & $\begin{array}{l}\text { Perpetrator } \\
\text { Red Flags }\end{array}$ & $\begin{array}{c}\text { Accounting } \\
\text { Red Flags }\end{array}$ \\
\hline Moral Development & Moral Development & $0.339^{* *}$ & $0.152^{*}$ & $0.326^{* *}$ \\
\hline
\end{tabular}

Table 4 shows the most significant correlation between the dimensions of moral development and the environment. The correlation coefficient value is 0.339 , indicate that when the auditee often changes public accounting firms, law offices, or financial managers, then it is related to relatively low moral development. The weakest correlation is shown in the relationship between dimensions of moral development and dimensions of the perpetrators. The correlation coefficient value of 0.152 indicates that the pressure, opportunity, and rationalization of the perpetrators of fraud are relatively unrelated to moral development.

\section{Discussions}

The influence of external auditor's moral development on fraud detection. Moral development has a positive and significant effect on fraud detection. The results show that the moral development of the external auditor had a positive and significant effect on fraud detection. If the external auditor's moral development is high, the ability to detect fraud will increase. The results of this study are in line with the findings of Bernardi (1994) explaining that if external manager auditors have high moral development, they show the ability to detect fraud better. While Abdolmohammadi and Owhoso (2000) found that the moral development of senior auditors influences the detection of fraud. Hammersley, (2011) stated that the ability to detect fraud is mostly obtained through training and not through experience. This ability can be improved through an increased ability to solve greater problems and epistemic motivation. The findings of this study differ from the results of research by Abdolmohammadi and Owhoso (2000), which states that the moral development of manager auditors does not affect fraud detection.

This study found that the moral development of external auditors had the strongest relationship with the environmental dimensions of the fraud detection variable. The environment, in this case, includes organizational culture and relationships with third parties. When there are often power struggles in the company environment, or there are selfish executives, or many employees often complain of discriminatory treatment, those are condition to potential fraud. The environment can also be seen from relationships with third parties, such as frequent changes in legal consultants or changes in the public accounting firm (especially suddenly). If the company frequently replaces legal consultants or accounting firms, these are red flags of fraud.

The lowest correlation is shown from the relationship between moral development and the perpetrator dimension, which indicates that the influence of moral development on fraud detection can hardly be 
detected from financial pressures, opportunities, rationalization, or individual behavior. The effect of external auditor's moral education on fraud detection. The results analysis of the effect of education on the detection of fraud found to have a positive and significant effect. It can be concluded that the higher the education of the external auditor, the better the ability to detect fraud. This study is in line with the results of previous studies which state that education has a positive effect on the ability to detect fraud (Dickerson, 2009; and Gadjali \& Birton, 2014).

Analyzing the influence of CPE on fraud on fraud detection that has a positive and significant effect indicates that the longer of CPE ob fraud duration, the better the detection of fraud. This study is in line with the results of previous studies, which stated that suggested the importance of training auditors to reason strategically to enhance fraud detection capabilities, (Hoffman \& Zimbelman, 2009). Noting the CPE on fraud, the findings of this study are in line with the results of the research of Bernardi (1994), which states that external senior auditors who have low moral development are unable to detect fraud. Also, in line with Hammersley (2011), which states that the ability to detect fraud is mostly obtained through training. This ability can be improved through an increased ability to solve greater problems and epistemic motivation. To be able to detect fraud, auditors need to analyze and integrate operational data (non-sample data populations) and utilize big data to recognize patterns of fraud. Also, external auditors need to believe that they are not in a submissive position on their auditee and not under threat or pressure by the auditee. The auditor's position must be independent, free from conflicts of interest and pressure. Consultation with experts should be carried out by involving forensic specialist accountants in general audit assignments (Asare, Wright, \& Zimbelman, 2015).

The public expects a public accountant to provide opinions on an entity's financial statements (Arens, Elder, \& Beasley, 2017), and the public expects auditors to be able to do more than before, which is to have the ability to detect fraud. Therefore, if the auditor has a clue or red flags or belief that fraud has occurred or is happening, they should contact an anti-fraud expert (Kranacher, 2012). Interventions in the form of conventional training or conventional ethical education could not significantly improve one's level of moral development. However, the level of formal education, age, and academic success can significantly improve one's moral development. It was also found that work experience cannot improve one's moral development. Therefore, to improve one's level of moral development, this research does not suggest the implementation of conventional ethics training/education in the business world or academic activities. This study also states that a person's level of moral development can increase with certain experiences learned previously (Cannon, 2001).

\section{Conclusion}

External auditors as guardians of the public interest have a significant role in providing added value to the financial statements made by management. Management's financial statements have an added value when external auditor gives a fair opinion on those financial statements, which means that it provides adequate assurance that the financial statements are free from material misstatement due to errors and fraud. However, various cases that occur indicate that external auditors are unable to detect frauds committed by company management when conducting general audits of financial statements. The audit procedures, the length of time required, and the scope of audit work for general audit purposes for financial statements are different from audit procedures to detect fraud. However, the public demand the external auditors to be able to detect all types of fraud when conducting general audits of financial statements. The existence of fraud that is not detected by the auditor and the number of cases of fraud that are published in the media involving external auditors' inability to detect fraud when conducting general audits makes this research relevant to deliver. The detection of fraud itself is not easy to recognize since the perpetrators of fraud have covered their tracks, coupled with the position of external auditors who are not entirely independent of the audit, and ethical issues that are often embedded in technical issues add to the difficulty of detecting fraud. How can external auditors recognize signs of fraud? One of the answers is by having a certain level of moral development.

Moral development has a positive and significant effect on fraud detection. The results showed that the moral development of the external auditor had a positive and significant effect on fraud detection. If 
the external auditor's moral development is high, the ability to detect fraud will increase. The results analysis of the effect of education on the detection of fraud has been shown to have a positive and significant effect. It can be concluded that the higher the education of the external auditor, the better the ability to detect fraud. Analysis of the effect of CPE fraud on fraud detection has a positive but not significant. It can be concluded that the higher the CPE fraud, the better the detection of fraud.

These findings show that accounting firm management needs to pay attention to the auditor's moral development. Training programs for enhancing moral development need to be developed, especially those that are suitable for men since there are more male auditors than females. The accounting firm management also needs to pay attention to the level of education of its external auditors, as well as refine its fraud detection training methods to have a positive and significant impact.

\section{Limitation}

One of the three scenarios for measuring moral development used is a scenario that is adjusted to the situation and regulations in Indonesia. The scenario developed is a scenario regarding audit opinion while maintaining the elements of independence value and staying in accordance with the laws and regulations for assurance services in Indonesia, and on the other hand, maintaining the ethical dilemma embedded in the scenario that may not appropriate to the situation and regulations in other regions other than Indonesia.

\section{Recommendation for Further Research}

Further research can replicate this research with external auditors working in public accounting firms with more respondents, or even further research can conduct studies of external auditors working in the supreme audit board, and internal auditors working in companies and working in ministries and institutions. Thus it is expected that further research results can better represent the situation of external auditors and the situation of auditors in general in Indonesia. Further research is also needed to improve the suitability of the model by adding other exogenous variables that affect fraud detection more than moral development, education, and CPE Fraud. Other demographic aspects, such as experience, position, gender, age, and marital status, can be further investigated as factors that influence fraud detection. Moral development is measured by modifying the audit opinion scenario to conform to Law No.5/2011 regarding public accountants by including an ethical dilemma in the form of respect for seniors vs. maintaining skepticism. Future studies are expected to be able to re-test such measurements with this scenario.

External auditors need to continue to improve their ability to detect fraud. This ability could be achieved by increasing knowledge, experience, and training in the detection of fraud on an ongoing basis. Audit procedures to detect and reveal fraud in many cases require procedures that are different from general audit procedures, for example, general audits can use samples in the audit process, while fraud audits use population data; therefore external auditors should consider the need to use populations when conducting a general audit. Thus the knowledge and skills of using tools are a must. The audit aids can also be connected to the auditee data server on an online basis so that the analysis of the latest data can be monitored online as well; this could greatly facilitate the work of the auditor at the end of the reporting period. Conventional ethics training or education cannot significantly increase a person's level of moral development; therefore, external auditors need to make certain non-conventional training interventions.

\section{References}

Abdol mohammadi, M. ., \& Owhoso, V. (2000). Auditors ' ethical sensitivity and the assessment of the likelihood of fraud. Managerial Finance, 26(11), 21-32. https://doi.org/http://dx.doi.org/10.1108/03074350010766963

ACFE. (2012). Report to the nations on occupational fraud and abuse.

ACFE. (2014). Report to the nations on occupational fraud and abuse.

ACFE. (2016a). Report to the nations, occupational fraud, and abuse.

ACFE. (2016b). The fraud tree. Retrieved from 
https://www.acfe.com/uploadedFiles/ACFE_Website/Content/rttn/2016/fraud-tree.pdf

ACFE. (2017). Fighting fraud in the government. Retrieved from https://www.acfe.com/uploadedFiles/Shared_Content/Products/Self-Study_CPE/Fighting Fraud_Chapter.pdf

ACFE. (2018a). Report to the nations, global study on occupational fraud and abuse.

ACFE. (2018b). Report to the nations 2018 global study on occupational fraud and abuse. AsiaPacific Edition. Retrieved from

https://www.acfe.com/uploadedFiles/ACFE_Website/Content/rttn/2018/RTTN-Asia-PacificEdition.pdf

Ajzen, I. (1991). The theory of planned behavior. Organizational Behavior and Human Decision Processes, 59, 179-211.

Arens, A. A., Elder, R. J., \& Beasley, M. S. (2017). Auditing and assurance services (Sixteenth). New Jersey: Pearson Education Inc: England: Pearson Education Limited.

Asare, S. K., Wright, A., \& Zimbelman, M. F. (2015). Challenges facing auditors in detecting financial statement fraud: Insights from Fraud Investigations, 7(2), 63-112.

Bailey, C. D., Scott, I., \& Thoma, S. J. (2010). Revitalizing accounting ethics research in the neokohlbergian framework: putting the DIT into perspective, 22(2), 1-26. https://doi.org/10.2308/bria.2010.22.2.1

Bernardi, R. A. (1994). Fraud detection: The effect of client integrity and competence and auditor cognitive style, 13, 28-29.

Cannon, C. (2001). Does moral education increase moral development? a reexamination of the moral reasoning abilities of working adult learners.

Dickerson, C. (2009). Ethical decision-making in public accounting: investigating factors that influence auditors 'ethical sensitivity.

Dorminey, J., Fleming, A. S., Kranacher, M., \& Riley, R. A. (2012). The evolution of fraud theory, 27(2), 555-579. https://doi.org/10.2308/iace-50131

Firth, M., Mo, P. L. L., \& Wong, R. M. K. (2005). Financial statement frauds and auditor sanctions : an analysis of enforcement actions in China. Journal of Business Ethics, 62, 367-368. https://doi.org/10.1007/s10551-005-0542-4

Fullerton, R. R., \& Durtschi, C. (2004). The effect of professional skepticism on the fraud detection skills of internal auditors the effect of professional skepticism on the fraud detection skills of internal auditors. Utah State University School of Accountancy, (39).

Gadjali, R., \& Birton, M. N. U. R. (2014). Analisis pengaruh jenis kelamin dan masa kerja terhadap persepsi etis akuntan manajemen dengan love of money sebagai variabel intervening. Simposium Nasional Akuntansi 17 Mataram, Lombok, 1-23.

Greer, L., \& Tonge, A. (2006). Ethical Foundations : A new framework for reliable financial reporting. Business Ethics, 15(3), 259-270.

Hair, J. F. J., Black, W. C., Babin, B. J., \& Anderson, R. E. (2014). Multivariate data analysis Joseph F. Hair, Jr. William C. Black Seventh Edition (Seventh Ed). England: Pearson Education Limited.

Hammersley, J. S. (2011). A review and model of auditor judgments in fraud-related planning tasks, 30(4), 101-128. https://doi.org/10.2308/ajpt-10145

Hayes, R., Wallage, P., \& Gortemaker, H. (2014). Principles of auditing an introduction to international standard on auditing (Third). United Kingdom: Pearson Education Limited.

Hoffman, V. B., \& Zimbelman, M. F. (2009). Do strategic reasoning brainstorming help auditors change do strategic reasoning and their standard audit procedures in response to fraud risk? 84(3), 811837. https://doi.org/10.2308/accr.2009.84.3.811

IAPI. Standar Audit 240, Tanggung jawab auditor terkait dengan kecurangan dalam suatu audit atas laporan keuangan (2013).

Jamal, K., Johnson, P. E., \& Berryman, R. G. (1995). Detecting framing effects in financial statements. Contemporary Accounting Research, 12(1), 85-105.

Jones, T. M. (1991). Ethical Decision Making by Individuals in organizations: An issue-contingent model. Academy of Management Review, 16(2), 366-395. Retrieved from http://www.jstor.org/

Kranacher, M. (2012). How to Detect Fraud (June).

Pincus, K. V. (1994). Discussion of Fraud detection: The effect of client integrity and competence and 
auditor cognitive style. Auditing. https://doi.org/10.2139/ssrn.1097127

Sweeney, J. T., \& Roberts, R. W. (1997). Cognitive moral development and auditor independence. Accounting, Organizations and Society, 22(3-4), 337-352. https://doi.org/10.1016/S03613682(96)00025-6

Welton, R. E., \& Guffey, D. M. (2009). Transitory or persistent? The effects of classroom ethics interventions : A longitudinal study. Accounting Education: An International Journal, 18(3), 273289. https://doi.org/10.1080/09639280802217990 